\title{
PAISAGEM MINERÁRIA COMO ELEMENTO DE CONSTRUÇÃO DO SENTIMENTO DE PERTENCIMENTO AO ESTADO DE MINAS GERAIS
}

\author{
Maraluce Maria Custódio ${ }^{1}$ \\ Escola Superior Dom Helder Câmara (ESDHC)
}

José Cláudio Junqueira Ribeiro² Escola Superior Dom Helder Câmara (ESDHC)

\section{RESUMO}

A paisagem é elemento fundamental para garantia de pertencimento dos indivíduos a sua comunidade local, regional e até mesmo global. Minas Gerais surge como uma província com feição minerária ainda no século. XVIII e, ainda hoje, tem a mineração como essencial para o desenvolvimento socioeconômico. As paisagens das cidades mineiras foram forjadas a partir dessa da mineração, que é importante elemento constitutivo da cultura de Minas Gerais. O presente artigo busca analisar a necessidade de proteger a paisagem minerária mineira como representação do próprio Estado, do pertencimento do mineiro a esse contexto e compreender a possibilidade de utilização das paisagens mineiras economicamente para desenvolvimento do turismo no Estado. Para a construção do artigo utilizar-se-á como marco teórico o conceito de paisagem da Convenção Europeia de Paisagem de 2000 e como metodologia os métodos indutivo e o dedutivo, tendo por técnica a bibliográfica, para, por fim, concluir que é necessário diferenciar paisagem de meio ambiente e compreender a importância da paisagem minerária, degradada na perspectiva ambiental, como representativa

\footnotetext{
1 Doutora em Geografia na Universidade Federal de Minas Gerais (UFMG), em programa de cotutela com a Université d'Avignon. Mestre em Direito pela UFMG e em Direito Ambiental pela Universidad International de Andalucía (UNIA). Graduada em Direito pela UFMG. Professora da graduação e professora permanente do Programa de Pós-Graduação em Direito da ESDHC (mestrado em Direito Ambiental e Desenvolvimento Sustentável). ORCID: https://orcid.org/0000-0003-2048-7883 e-mail: maralucem@hotmail.com

2 Doutor em Saneamento Meio Ambiente e Recursos Hídricos pela UFMG. Mestre em Genie Sanitaire Et Urbanisme pela Ecole Nationale de La Santé Publique (ENSP). Especialista em Engenharia Sanitária pela Escola de Engenharia da UFMG. Graduado em Engenharia Civil pela UFMG. Professor da graduação e professor permanente do Programa de Pós-Graduação em Direito da ESDHC (mestrado em Direito Ambiental e Desenvolvimento Sustentável). ORCID: https://orcid.org/0000-0002-66264557 / e-mail: jcjunqueira@yahoo.com
} 
da sociedade mineira e garantia do pertencimento dos indivíduos às comunidades e a real possiblidade de utilizá-la como fonte de recursos para a manutenção econômica das cidades após o fim da atividade minerária.

Palavras-chave: direito à paisagem; Minas Gerais; paisagem minerária; pertencimento; turismo minerário.

\section{MINING LANDSCAPE AS AN ELEMENT OF SENSE OF BELONGING TO THE STATE OF MINAS GERAIS}

\section{ABSTRACT}

The Landscape is a key element for the sense of belonging to local, regional and even global community. Minas Gerais emerges as a province with mining features in the century XVIII, and even today, has mining as essential socioeconomic source. The landscapes of the mining cities were forged from this mining, which is an important constitutive element of the culture of Minas Gerais. This article seeks to analyses the need to protect the mining landscape as a representation of the state itself, from the belonging of the miner to this context and understand the possibility of using the mining landscapes economically for tourism development in the state. For the construction of the article, the concept of landscape of the 2000 European Landscape Convention of 2000 will be used as theoretical framework, and as a methodology the inductive and deductive methods, using the bibliographic technique, to conclude, finally, that it is necessary to differentiate landscape from environment and for understand the importance of mining landscape, degraded in environmental perspective, as representative of the mining society and guarantee of the belonging of individuals to communities and the real possibility of using it as a source of resources for the economic maintenance of cities after the end of mining activity.

Keywords: belonging; Minas Gerais; mining landscape; mining tourism; right to landscape. 


\section{INTRODUÇÃO}

A paisagem é elemento fundamental para garantia de pertencimento dos indivíduos a sua comunidade local, regional e até mesmo global. Ela, inicialmente percebida como bela e, posteriormente, como objeto da Geografia, chega ao século XXI como essencial para garantia de reconhecimento do sujeito como pertencente a uma comunidade.

Minas Gerais surge como uma província com feição minerária ainda no século. XVIII e, ainda hoje, tem a mineração como elemento chave para o desenvolvimento socioeconômico.

As paisagens das cidades mineiras foram forjadas a partir dessa história minerária e a mineração é importante elemento constitutivo da cultura de Minas Gerais. Assim, o presente artigo busca analisar a necessidade de garantir a proteção da paisagem minerária mineira como representação do próprio Estado, o pertencimento do mineiro a esse contexto e compreender a possibilidade de utilização das paisagens industriais mineiras economicamente para desenvolvimento do turismo no Estado.

A pesquisa justifica-se por ser a mineração uma atividade modificadora do ambiente, transformando paisagens em função de seu potencial extrativista, mas também elemento essencial na formação não apenas de um estado brasileiro, mas de toda a cultura do povo mineiro que carrega seu nome na própria identidade de ser.

A exploração mineral no Estado de Minas Gerais é bem anterior à preocupação ambiental iniciada pela Convenção de Estocolmo de 1972 e as modificações geradas pela mineração foram lentas e incorporadas às sociedades e por elas constituídas, compondo uma verdadeira paisagem que representa a sociedade a ela vinculada, e, na qual os indivíduos se reconhecem como pertencentes. Para a construção do artigo, utilizar-se-á como marco teórico o conceito de paisagem da Convenção Europeia de Paisagem de 2000 e como metodologia os métodos indutivo e o dedutivo, tendo por técnica a bibliográfica, para por fim comprovar a necessidade de diferenciar paisagem de meio ambiente e a necessidade de compreender a importância da paisagem minerária, degradada na perspectiva ambiental, como representativa da sociedade mineira e garantia do pertencimento dos indivíduos às comunidades onde a mineração se desenvolveu. Comprovando que, por isso, deve-se buscar sua necessária proteção e compreender a real possiblidade de utilizá-la como fonte econômica para a manutenção econômica das cidades após o fim da atividade minerária. 
Inicialmente são apresentados conceitos, elementos e tipos de paisagem e a importância de sua proteção como bem cultural. Na sequência, a paisagem minerária como elemento de pertencimento das sociedades mineiras e a importância dos aspectos culturais no processo de fechamento de minas. Finalmente são apresentadas experiências internacionais de sucesso para recuperação de áreas mineradas, considerando a paisagem minerária como elemento de conservação do ambiente, que poderiam inspirar alternativas para Minas Gerais.

Isso será demonstrado a partir da analise de casos de regiões na França, Alemanha e Espanha, que muito se assemelham a Minas Gerais e nos quais proteção da paisagem minerária como elemento constitutivo da sociedade vem apresentando grande apelo para o desenvolvimento do turismo, que se tornou importante atividade econômica nessas regiões.

\section{PAISAGEM}

A paisagem surge da interseção entre sociedade e o meio em que vive e construiu, sendo a representação da própria cultura social e, portanto, mutante como ela.

No imaginário social ocidental, ela surge com as representações dos pintores ainda no período do Renascimento, entretanto, sua representatividade é bem anterior. No Egito antigo já existiam jardins apenas para deleite e na China já se representava a relação entre seres humanos e meio por meio de figuras picturais (CUSTÓDIO, 2014).

A construção histórica no Ocidente de sua existência inicia-se com os pintores e sua representação em quadros que determinavam o que merecia ser visto e admirado, passando a sua representação paisagística dos jardins (como o de Versailles), onde o ser humano constrói o belo, pois este não está na natureza. A segunda fase de como a paisagem é percebida surge com o Cientificismo do século XIX. Passa a ser o objeto de estudo da Geografia, trazendo elementos estruturados que conformam o que seria a paisagem, tais como: estratos de solo, ou formações, bem como configurações estruturais ou unidades paisagísticas. Para por fim, chegar a atualidade que se inicia no fim do século XX juntamente com o início da expansão do estado democrático. A paisagem passa a ser vista como a representação do que a sociedade a ela interligada interpreta como importante de proteger. Para isso, não interessa mais se merece ser retratado - ou seja, é belo no sentido geral, ou se tem estratos geológicos ou geográficos excepcionais, 
mas, sim, sua representatividade para aquela comunidade local, regional, nacional ou mesmo planetária.

O valor do estético foi muito desigual ao longo da história e isto é possível de observar através da literatura de cada época, em particular, em relação às cidades e centros urbanos. Em alguns períodos a beleza foi considerada puramente subjetiva. Em outros, entretanto, os parâmetros de beleza estavam absolutamente submetidos à razão. De modo que existem numerosas prescrições sobre as formas materiais, proporções ou cores, que o sentido de ideais que tem, varia a cada momento histórico (RODRÍGUEZ, 2007, p. 53).

Assim, a paisagem estabelece coletivamente os critérios do que deve ser protegido, sempre considerando que a sociedade está em constante mutação, logo para acompanhar essa mudança e ser sempre representação social, a paisagem deve ser mutante. Se não reconhecida, deixa de ser "vista" e, portanto, esquecida e por isso pode ser destruída. Neste ponto, deve-se compreender que a paisagem não é o meio ambiente nem com ele se confunde, pois muitas vezes persiste a ideia de manter o ambiente intocado ou que não seja modificado, seja em sua feição natural ou artificial. Morais e Saraiva (2018, p. 31) demonstram tal perspectiva "para a construção de um Estado de Direito Socioambiental, a constitucionalização, na esfera global, do Princípio Fundamental do Nível Elevado de Proteção Ecológica, como ponto de partida e como limite interno e externo aos Estados". A paisagem, diferentemente, pode até ser funcional ou mesmo imutável, mas estas não devem ser um pressuposto, porque ela deve ser somente representativa para garantia de sua proteção. Essa representação como feição democrática que deve ter reflete a sociedade e sua cultura naquele momento e, por isso, deve ser um projeto coletivo, para garantia do sentimento de pertencimento, e assim a coletividade se reconheceria e lutaria por sua existência. Isso pode ocorrer pela educação paisagística, ou seja, refletir sua existência e manter o sentimento construído com o passar das gerações de que é importante e faz parte da estruturação daquela sociedade.

Com a afirmação do estado democrático de direito na segunda metade do século XX, vários segmentos, percepções de mundo e direitos tem sido repensada como direitos dos idosos, portadores de necessidades especiais, participação social e a possibilidade de a sociedade pensar seus próprios caminhos. Não há mais espaço para imposições de padrões como antes ocorria, criando imaginários fictícios e desligados da realidade vivida. Chega o momento de cada ser humano se reconhecer em seu espaço e valorizá-lo e ser valorizado por isso, criando então a paisagem. 


\subsection{Conceito de paisagem}

O conceito de paisagem variou ao longo do tempo, mas para este trabalho será utilizado o conceito propagado pela Convenção Europeia de Paisagem de 2000 que define "Para os efeitos da presente Convenção: (a) 'Paisagem' designa uma parte do território, tal como é apreendida pelas populações, cujo carácter resulta da ação e da interação de fatores naturais e ou humanos" (PORTUGAL, 2005), e continua no art. $2^{\circ}$ :

Sem prejuízo das disposições constantes do artigo $15^{\circ}$, a presente Convenção aplicase a todo o território das Partes e incide sobre as áreas naturais, rurais, urbanas e periurbanas. Abrange as áreas terrestres, as águas interiores e as águas marítimas. Aplica-se tanto a paisagens que possam ser consideradas excepcionais como a paisagens da vida quotidiana e a paisagens degradadas (PORTUGAL, 2005).

Nela se percebe a mudança. Hoje, nas sociedades paisagísticas, os conceitos estéticos são da sociedade. O conceito de paisagem forma-se a partir da indissociabilidade entre a construção material do espaço (natural e artificial e sua interação), uma percepção e a representação que tem (MARCEL, 2006). Dessa forma, ela funciona como uma mediação social, o caminho em que a sociedade se reconhece como tal. É como um filme onde cenário e atores formam um todo indissociável e formam um sistema do qual todos fazer parte e se reconhecem como tal. Por isso "a paisagem só é visível para quem sabe reconhecer e somente um olhar conscientemente educado pode descobrir essa essência encantadora do mundo" (PRAT, 1999, p. 39, tradução nossa).

A existência humana e a interpretação do mundo estão relacionadas a um lugar, momentos representados por sons e cheiros - paisagem sonora e olfativa - que relembram seu pertencimento a uma sociedade, a própria interpretação do momento liga-se à vivência em um local.

Durante muito tempo, se pretendeu analisar a ação dos sujeitos separadamente do lugar onde ocorre. Com frequência se esquece que os lugares ligados às vivencias dos sujeitos, definem decisivamente os conteúdos das mesmas, ajudam a reconhecer e a recuperar essas mesmas vivencias (VYGOTSKY, 2009, p. 1).

Para além disso, sempre se busca entender a ação dos sujeitos e sociedades em um determinado local e ambiente, esquecendo-se de como este atua naqueles e em sua interpretação da realidade. A paisagem nos reenvia a nós mesmos e dessa interpretação surgem as ações. Por isso, deve-se ter cuidado, pois, se ela não representa uma totalidade, mas, apenas 
um grupo tende a perder-se no tempo e espaço "a cultura erudita tendera a apagar a cultura tradicional e os conflitos sociais serão esquentados pelos eficazes procedimentos pedagógicos. Do ponto de vista da analise etnológica, na cultura urbana repousarão os valores tradicionais onde ou os exaltarão até o folclore caricaturesco" (DONAUDIEU; PERIGORD, 2005, p. 129, tradução nossa). Para além disso, uma pseudocultura globalizante pode conduzir a planificação do que deve ou não ser paisagem, como de certa forma faz a Unesco em termos de patrimônio histórico. Ou mesmo, como a Chancela da Paisagem - Portaria n. 127/2009 do Instituto do Patrimônio Histórico Nacional, que dá o conceito de paisagem reconhecido no Brasil, faz. A abertura interpretativa deve ser realizada, como feito pela Convenção de paisagem europeia sob pena de perda, sem retorno de várias paisagens., pois “a paisagem não pode ser reduzida a um simples objeto impregnado de subjetividade ela condiciona pelos valores que são projetados na nossa vida e nossa identidade. Portadora de valores [...]" (DONAUDIEU; PERIGORD, 2005, p. 26, tradução nossa), ela não pode ser restrita a valores universais de configuração, não que estes não devam ser consideramos, mas não podem ser determinantes, já que

\footnotetext{
[...] criar a imagem de uma paisagem é um processo complexo. Paisagem é fundamental para uma pessoa ou comunidade e seu senso de pertencimento e identidade onde dividiram experiências e eventos dividiram memorias e histórias. $\mathrm{O}$ ato de relembrar é um ato de ritualização. A pratica de retornar a um lugar, relembrar o lugar é praticada como um ritual e leva o lugar a ser sacralizado na memora da comunidade (STEWART; STRATHERN, 2003, p. 7).
}

Ao pensar, por exemplo, o caso de Bento Rodrigues, pode-se perceber esse sentido quando as exigências dos ex-moradores passam por manter sua casa como era, ou seu vizinho seja o mesmo que era. Isso demonstra o reconhecimento enquanto parte da sociedade, não importando se qualquer órgão ou a empresa que reconstruirá a cidade pense em fazê-la mais moderna ou eficiente do que era, pois se perdem os vínculos com o espaço, perde-se a identidade, daí a necessidade de garantir sua proteção.

\subsection{Proteção da paisagem}

Como dito, a paisagem é uma representação coletiva criada democraticamente e por isso sua proteção deve ser garantida legalmente. No Brasil, a história da proteção da paisagem inicia-se com o Decreto-Lei n. 25/37, que assim define: 
Art. $1^{\circ}$ Constitue o patrimônio histórico e artístico nacional o conjunto dos bens móveis e imóveis existentes no país e cuja conservação seja de interesse público, quer por sua vinculação a fatos memoráveis da história do Brasil, quer por seu excepcional valor arqueológico ou etnográfico, bibliográfico ou artístico. [...]

$\S 2^{\circ}$ Equiparam-se aos bens a que se refere o presente artigo e são também sujeitos a tombamento os monumentos naturais, bem como os sítios e paisagens que importe conservar e proteger pela feição notável com que tenham sido dotados pela natureza ou agenciados pela indústria humana (BRASIL, 1937).

E passa uma série de leis que a inserem como importante em diversos contextos como por exemplo no turismo como aparece na Lei n. 6.513/77, para proteção da natureza como aparece na Lei do Sistema Nacional de Unidades de Conservação, Lei n. 9.985/2000, o Código Florestal, Lei n. 12.651/2012; ou mesmo no contexto da cidade como aparece no Estatuto das Cidades, Lei n. 10.257/2001. Mas incontestável é que toda essa proteção tem vínculo constitucional incontestável como determinam os arts. 216 e 216 a da Constituição Federal de 1988.

Hoje, em termos de proteção de paisagem no geral, o que mais se tem veiculado é a Chancela da Paisagem, pois além de definir paisagem (cultural), estabelece estratégias de proteção desta.

Apesar da Chancela ser um importante instrumento e muito usado em todas as áreas que versam de proteção de paisagem, ela peca pela forma legal já que portaria segundo Hely Lopes Meirelles (2001, p. 176), são "atos pelos quais os chefes de órgãos, repartições ou serviços expedem determinações gerais ou especiais a seus subordinados que não produzem efeitos externos, isto é, não obriga os particulares" e que conceitos devem ser criados legalmente para serem validados de forma indiscutível. No Brasil, essa definição ainda não existe, dando fragilidade à proteção. Além disso, o conceito apresentado pela Chancela é restritivo, por se tratar de proteção à paisagem cultural, não tendo a perspectiva ampla que a convenção europeia traz, como visto. A novidade é a possibilidade de o Brasil assinar a convenção de paisagem como determinado pelo Conselho Europeu, no Relatório de Encontro das Partes de 2017, e assim reconhecer o conceito, inicialmente europeu.

Esta universalidade tornou possível a extensão da Convenção Europeia da Paisagem a Estados não europeus, enquanto inicialmente a Convenção Europeia da Paisagem apenas visava a especificidade da identidade europeia. Por exemplo, o Protocolo que altera a Convenção Europeia da Paisagem, adotado pelo Comité de Ministros 
em 15 de junho de 2016 na sua 1260. ' reunião e aberto à ratificação, aceitação ou aprovação em 1 de agosto de 2016, permitirá no futuro proteger, gerenciar e organizar as paisagens de acordo com princípios comuns aplicáveis à diversidade de paisagens ao redor do mundo. De fato, em todos os continentes, as paisagens sempre refletem identidades culturais locais e regionais. Dadas as ameaças crescentes de banalização e padronização de paisagens em escala global, uma boa gestão das paisagens no mundo, que pode ser baseada em princípios e diretrizes inteligíveis para todos, tornou-se uma necessidade urgente. Isto é tanto mais necessário quanto a consciência do público e das autoridades eleitas sobre a importância, agora universal, da paisagem para a qualidade de vida (PRIEUR; LUGINBÜHL, 2017, p. 28).

Tal reconhecimento facilitaria a proteção da paisagem no Brasil ampliando e abrindo a discussão sobre a paisagem ser um elemento de construção democrático e possibilitando sua proteção em sua totalidade e por tabela a proteção das diferenças culturais que em um país como o Brasil, são grandes, com isso impossibilitando a pasteurização cultural, por ser o conceito da paisagem polissêmico e ter por base o desenvolvimento sustentável que tem como um dos elementos o desenvolvimento social que é sempre cultural. Assim, a importância da paisagem como garantidor da qualidade de vida dos habitantes vai incrementar para além da realidade atual, transparecendo mais claramente sua função de agregadora social e garantidora da identidade social. Para realizar isso, deveriam ser reordenadas as normas de organização do território, composta por normas de restrição de uso, de ações públicas, de sistema de recompensas (redução de impostos, aumento de incentivos, dentre outros) como forma de proteção, gestão e/ou transformação.

Para proteger é importante conhecer o que proteger e para tanto é necessário identificar os elementos que compõe a paisagem.

\subsection{Elementos da paisagem}

A paisagem é composição de diversos elementos e variadas feições, por isso devem ser consideradas para compreender a unidade paisagística: sua textura, complementariedade, contrastes, escalas, formas que se repetem, possibilidades de visualização, entorno, representação. Assim, para Roger a paisagem pode ser um local considerado degradado, pois seria essencialmente uma experiência sensorial ligada aos aspectos formais (FORTIN, 2003).

A paisagem é formada por três elementos principais que coadunam uma série de outros elementos transversais em seu contexto. Analisaremos 
rapidamente cada elemento para poder compreender melhor essa formação da paisagem bem como a necessidade e formação de um projeto social ligado a ela.

A paisagem, para ser considerada como tal, deve ter segundo Custódio (2014): o elemento espacial delimitado, o elemento humano e o elemento subjetivo

O elemento espacial é formado por um conjunto de componentes determinados tecnicamente em todos os seus aspectos: pedológicos, hidrológicos, ecológicos, bióticos fitogeográficos e o grau de antropização. Estes são analisados com um recorte temporal e espacial. Esse elemento físico deve ser conservado, seja ele formado pelo meio ambiente ou pela degradação deste, desde que sua importância seja reconhecida socialmente.

Aqui é importante diferenciar conservar de preservar, pois no direito brasileiro geralmente tais termos aparecem como sinônimos. Preservar é buscar a integridade e a perenidade de algo segundo Suzana Padua (2006) "O termo se refere à proteção integral, a "intocabilidade". A preservação faz-se necessária quando há risco de perda de biodiversidade, seja de uma espécie, um ecossistema ou de um bioma como um todo", já a conservação, entretanto apesar de buscar a proteção, permite o uso sustentável e assume um papel de guardar, mas sempre buscando a integração dos fatores naturais e culturais. "Na conservação a participação humana precisa ser de harmonia e sempre com intuito de proteção" (PADUA, 2006).

Por isso é importante a utilização do termo conservar, pois assim garante a mutabilidade natural e mesmo artificial do elemento espacial, que de certa forma se confunde com meio ambiente, mas que dele se difere pela necessária mutabilidade e por não necessitar ser ecologicamente equilibrado como define o art. 225 da $\mathrm{CF} / 88$.

O elemento humano é a sociedade ou comunidade que observa o elemento espacial e lhe dá significação dentro de seu contexto sociocultural e histórico-econômico, sendo necessariamente um projeto social para garantia de sua efetiva proteção ao longo das gerações e ser democraticamente reconhecido como paisagem. Sem o ato de ver ou sentir pelo observador, não há que se falar em paisagem. Disso surge a necessidade de pontos de visualização, a paisagem deve necessariamente ser vista para ser reconhecida e não perder sua função de representação social.

A percepção surge a partir da visão do elemento espacial pelo elemento humano. Essa percepção é a imagem que o observador cria do elemento 
espacial e que tem significado para ele a partir do ponto de observação que usa, bem como seus sentimentos, sua história, seu estado emocional e mental, como bem demonstra a Figura 1.

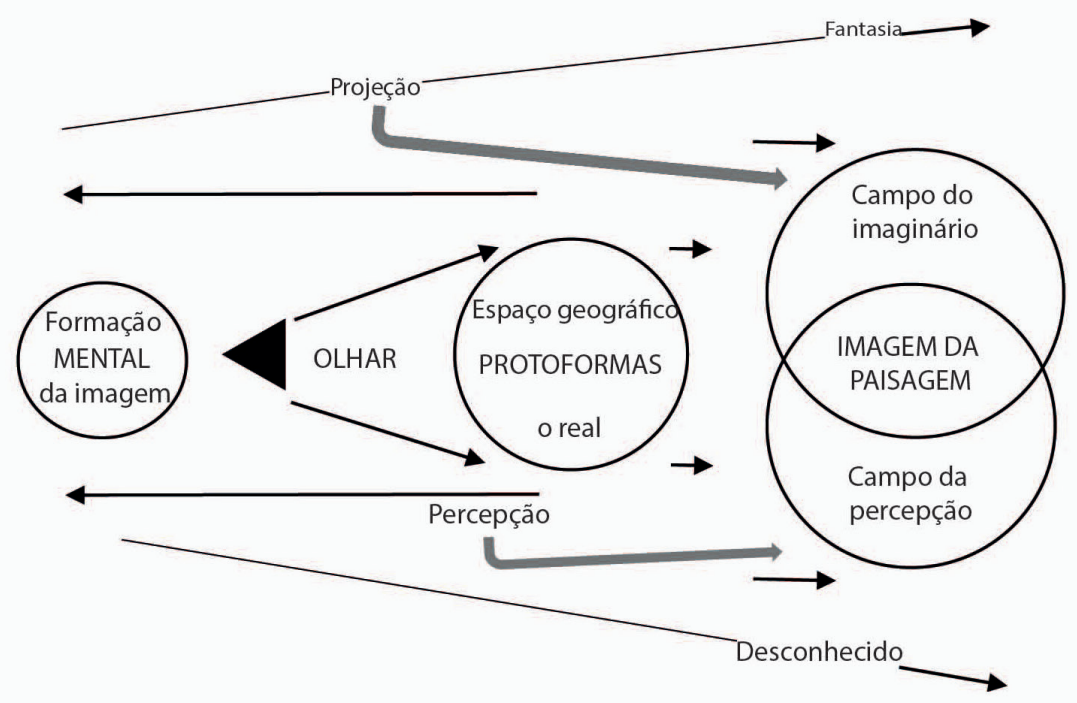

Figura 1 Fomação da percepção da paisagem.

Fonte: adaptada de Donaudieu e Perigord (2005 apud CUSTÓDIO, 2014, p. 92).

Percebe-se que a paisagem vai além de sua espacialidade, ela é reprodução de valores da comunidade. Ela representa sua história, sua atualidade e, por isso, deve ser protegida para as futuras gerações, ou seja, é intergeracional, avançando além para além de uma única geração e sendo protetora e representação das três perspectivas: passado, presente e futuro. Surge, assim, uma linha temporal de inserção social da paisagem e dos próprios indivíduos que percebem sua pertença ao passado e aquele local e querem ver seus filhos também como parte dessa cultura social. Por exemplo, uma cidade fundada com base na mineração, tem que refletir como esta se insere como valor e nos valores da sociedade que se insere. E por isso, as sociedades devem participar das definições e decisões sobre o futuro ou fim da mina e isso deve ser incitado pelas normas. Com essa garantia, inicia-se a tomada de consciência de sua importância, bem como a obrigatoriedade de educar e informar, isso passa também por compreender os tipos de paisagem que apesar de não serem fixos estabelecem critérios de 
reconhecimento para que estabeleça o que é reconhecido como paisagem na feição cultural analisada.

\subsection{Tipos de paisagem}

Existem várias tipologias de paisagem, até porque cada comunidade pode inventar sua própria paisagem ordinária - aquela que não é monumental - construída por meio de seus sentimentos e olhar. Segundo Donaudieu e Perigord (2005, p. 9, tradução nossa), “Algumas sociedades inventaram formas e modelos para analisar, enquanto outras se contentam em reproduzir suas heranças sem entender o escopo. Por essas razões, as formas da paisagem constituem grandes desafios para cada sociedade".

A tipologia adotada neste trabalho é de Donaudieu e Perigord (2005) por contemplar mais que as paisagens tradicionais, inserindo novas formas reconhecidas por organismos internacionais e pela própria sociedade.

Donaudieu e Perigord (2005) dividem a paisagem em cinco grandes tipos e as subdivide segundo suas especificidades, sendo: paisagens de Herança rural e natural, paisagens institucionais, paisagens de miséria e do esquecido, paisagens de criação e (re)criação e o tipo que interessa a este artigo as paisagens urbanas, industriais ou de lazer.

As paisagens urbanas, industriais ou de lazer são aquelas que foram constituídas para uma funcionalidade, mas acabaram tornando-se um ponto representativo ou pictural, logo, tornando-se uma paisagem que busca ser protegida pelas sociedades. A mineração inserir-se-ia na Paisagem Industrial, que, segundo Custódio (2014, p. 113),

[...] foram criadas principalmente nos séculos XIX e XX como expressão por vezes de orgulho nacional, por serem símbolos de desenvolvimento e progresso tecnológico, fundadas na exploração dos recursos minerais e energéticos. Elas têm um conjunto arquitetural de uma estética impressionante devido a sua audácia. A mineração insere-se nesse contexto.

\section{PAISAGEM E MINERAÇÃO}

A atividade extrativista está na base do desenvolvimento da humanidade, sendo a extração de minérios que ensejou a fabricação de artefatos para empoderar os diversos povos no desenvolvimento de técnicas para a obtenção de alimentos pela agricultura e caça, e também para a fabricação de armas para defender-se ou estender seus domínios. 
Um processo de mineração não pode ser realizado em curto prazo e depende do cumprimento dos princípios ambientais e da paisagem na atualidade. Mas nem sempre existiram regras para exploração, ou esta foi vista como algo negativo ou poluidor. Por isso é necessária uma rápida olhada na história da mineração.

\subsection{Mineração}

As eras da Pedra e da Pedra lascada, cerca de 2,5 milhões atrás, podem ser consideradas o início do extrativismo mineral com a utilização de fragmento de rochas para fabricação de ferramentas de corte. Em períodos mais recentes, cerca de dez mil anos a.C. a transição da cultura nômade para sedentária, quando várias tribos passam a fixar-se em áreas de seu domínio, época do surgimento da agricultura, inicia-se a extração de materiais da terra, como argila para fabricação de utensílios domésticos para estocagem de água, alimentos, artefatos religiosos e mesmo objetos de arte.

Para os historiadores (GHISLANZONI; DACAL, 2014), a Idade da Pedra termina com a Era dos Metais, cerca de 5 mil anos a.C. quando alguns povos passam a dominar a técnica da fundição, utilizando-se da extração de cobre e estanho para fabricação de bronze, liga metálica mais maleável, o que permitia o desenvolvimento na produção de artefatos e armas.

$\mathrm{Na}$ Antiguidade, metais nobres como o ouro e a prata também foram objeto de grande exploração. A chamada Idade do Ferro, posterior à Idade do Bronze, foi de grande importância para o desenvolvimento na fabricação de artefatos e armas por ser um dos minerais mais abundantes na crosta terrestre.

A extração de metais nobres como ouro, prata e pedras preciosas para produção de artefatos, decoração e joias, desde a antiguidade foram símbolos de riqueza e prestígio. Egípcios, fenícios e romanos são exemplos de como o conhecimento das técnicas do extrativismo e da capacidade de trabalhar os metais contribuíram para o desenvolvimento de suas civilizações. Na história mais recente, Portugal e Espanha tiveram seu apogeu com a descoberta e exploração de minas no Novo Mundo. Mesmo na atualidade, o extrativismo e o beneficiamento de minerais constituem em importante base para a indústria e o comércio, que potencializados pelo avanço tecnológico se destacam cada vez mais como fator do poder econômico (RIBEIRO, 2017, p. 12). 
Ao longo dos anos, a evolução do conhecimento ensejou o desenvolvimento de várias ciências, inclusive da geologia, permitindo a identificação de jazidas dos mais variados minerais existentes na crosta terrestre. A revolução industrial no século XVIII atuou como uma mola propulsora para a demanda da utilização desses vários minerais, que com o uso da pólvora para facilitar os desmontes das rochas e da dinamite. A partir do século XIX, permitiu-se, de uma forma acelerada, o acesso aos minerais para alimentar a crescente indústria metalúrgica, cujos produtos seriam cada vez mais demandados para as mais diversas utilizações na atual sociedade de consumo.

A mineração, especialmente do carvão, foi o eixo central para o progresso da tecnologia industrial. A aplicação das bombas e máquinas a vapor, num ramo de vital importância, crescente até meados do século XVIII, foi o primeiro passo para a siderurgia, com a substituição da lenha pelo carvão mineral. No caso da máquina a vapor, a mineração lhe forneceu os elementos essenciais, ferro e carvão, e dela recebeu mais tarde, contribuições indiretas sob a forma de mecanismos de extração, equipamentos, transportes sistemas de ventilação, etc. (RIBEIRO, 2017, p. 14).

De fertilizantes para a agricultura, passando pela construção civil, eletrodomésticos, celulares, veículos, foguetes, até cosméticos, a sociedade atual está inteiramente dependente da atividade extrativista de minerais.

Se, por um lado, a mineração está na base da cadeia dos bens e serviços que proporcionam melhoria na qualidade de vida, por outro, não se pode esquecer os efeitos colaterais em seus processos de exploração e beneficiamento, traduzidos como impactos ambientais negativos.

O extrativismo do bem mineral pode ocorrer a céu aberto ou em minas subterrâneas. Ainda que nas minas a céu aberto as alterações da paisagem natural sejam mais significativas, nas duas modalidades os estéreis e rejeitos passaram a compor novos elementos, modificando o campo de visão do observador.

Para a mineração a céu aberto, há necessidade da remoção da cobertura vegetal e da camada superior do solo até atingir o veio mineral, onde a concentração do minério justifique seu aproveitamento econômico. A escavação em bancadas aprofunda-se até o esgotamento do minério objeto da exploração, muitas vezes atingindo o lençol freático, sendo necessário seu rebaixamento. Essa escavação é chamada de cava, cuja exploração ocorre com base em um Plano de Lavra, que determina os limites finais da cava. A área final explorada da cava é denominada Pit final da mina.

A visão de uma mineração a céu aberto em operação, ou mesmo de uma 
mina exaurida, normalmente tem provocado uma sensação desagradável aos olhos do observador. Durante anos, na disciplina Poluição do Ar, Visual e Sonora do curso de engenharia ambiental da Universidade Fumec, centenas de alunos ao serem instados a listarem os principais exemplos de poluição visual, nove entre dez, apontaram a mineração. A imagem da terra desnuda, escavada, árida, sem presença de vida para muitos transmite ideia de abandono, desolamento e degradação ambiental.

Do material escavado, grande parte será composta por estéreis, uma vez que não apresentam concentração economicamente viável do minério explorado, e de rejeitos do processo de beneficiamento para aumentar a concentração do minério desejado. No beneficiamento ocorrem processos físicos como moagem e muitas vezes também processos físico-químicos como flotação, por exemplo, largamente utilizado no beneficiamento para o minério de Ferro no Estado de Minas Gerais.

Tais tipos de mineração modificam a paisagem existente ao longo do tempo criando novos tipos que vão se tornando parte da visão de mundo da comunidade e familiares a ela. Ao termino da mineração essa relação tem que ser considerada na questão de recomposição ambiental.

\subsection{A mineração no imaginário social das comunidades minerárias}

A mineração foi e é base ainda hoje para a construção de diversas cidades, sendo a cultura e a socialização construídas em torno dela. Mais que isso muitas sociedades foram forjadas tendo a mineração como preceito social indissociável. Não se pode negar que o trabalho é parte da personalidade dos indivíduos, tanto assim que, quando se conhece alguém novo, a primeira pergunta é o nome, e a segunda, que atividade exerce.

Numa cidade onde a mineração esteve presente por 50, 100 ou mais anos é impossível esta não fazer parte do imaginário social da comunidade ou de como seus membros interpretam o mundo. Ela está ali e é elemento visível e frequente, forjando culturas, sendo um exemplo significativo disso é a criação de um dialeto chamado "Camaco" na cidade de Itabira (MG), criada pelos mineiros para comunicar-se num período em que a mineração era exercida por ingleses na citada cidade e estes falavam uma língua que impossibilitava a todos entenderem suas motivações ou como agiam (LAMEGO et al., 2012). Isso incitou os mineiros a criar uma língua própria para que os donos da empresa, os ingleses, também não os compreendessem. 
Não é possível negar a existência de uma paisagem minerária que é reconhecida e é representação de várias sociedades em várias partes do mundo.

Hoje com a lógica ambientalista, a mineração sofre uma grande pressão de recompor o meio ambiente, ou criar um que seja mais palatável com os novos conceitos ambientais surgidos a partir da Convenção de Estocolmo de 1972 e que vem sendo atualizados e ampliados desde então.

A tendência ambiental é considerar a mineração como algo destruidor, que degrada, que ofende aos olhos.

"Em quase todos os casos conhecidos, o fim da exploração mineral causou uma série de problemas sérios, o "drama socioeconômico inevitável do fechamento do poço" (BAETEN et al., 1999 apud WIRTH; ČERNIČ; FISCHER, 2012, p. 14, tradução nossa). Primeiramente, a mineração tem sido causa da degradação ambiental em quase todos os lugares. As cidades afetadas são geralmente sobrecarregadas por instalações de mineração em desuso, assentamentos de mineiros e, muitas vezes, infraestruturas superdimensionadas e dilapidadas. A linha da mineração mergulha todos os fundamentos econômicos de uma região em crise. Alta taxa de desemprego com todos os impactos sociais associados (WIRTH; ČERNIČ; FISCHER, 2012). Em termos de paisagem, entretanto, essa perspectiva não se mantém. A mineração e seus efeitos, podem ser elementos paisagísticos a serem protegidos legalmente, se assim a sociedade desejar, pois sua representatividade social dentro do direito de paisagem é mais importante. A reestruturação ecológica e cultural de uma antiga região industrial foi vista como base necessária para uma renovação abrangente. Tradições deixadas pelo passado de mineração que podem ser valorizadas para promover o desenvolvimento pós-mineração. É de importância crucial para o desenvolvimento de antigas cidades e regiões de mineração: identificar esses potenciais e incorporá-los nas estratégias gerais de desenvolvimento (por exemplo, planos de ação, planos de regeneração) (WIRTH; ČERNIČ; FISCHER, 2012). Como já apresentado, a paisagem difere-se do meio ambiente e o reconhecimento e proteção daquela é bem anterior a este. A paisagem é representação cultural, reflete história e sentimento de uma comunidade. Assim, uma comunidade em que a mineração faça parte de sua história esta deveria ser considerada digna de proteção, ainda que os elementos da mineração não sejam ambientalmente corretos na atual perspectiva ou dignos de proteção no contexto global atual. Nesse momento há a separação clara entre o que protege o direito 
ambiental e o direito de paisagem. Na noção ambiental, o meio já destruído deve ser reparado, enquanto na noção paisagística ele pode ser a representação histórica e mesmo sentimental da comunidade e deveria ser protegido. Caberia à sociedade participar da decisão do que seria o melhor a ser realizado, com auxilio técnico e jurídico, de forma a encontrar um meio termo entre proteção ambiental e paisagem. A definição técnica de recompor sem ouvir a sociedade pode provocar uma perda de vinculação desta com o meio e com isso uma desagregação social. A paisagem não é apenas uma concepção estática do meio ambiente. Ao contrário, ela deve acompanhar a sociedade e transformar-se com ela de forma a continuar sempre representativa e pertencente à vida dos indivíduos, que, assim, mantêm sua proteção. Ela não é apenas o belo, mas sim, um significante para a sociedade que representa. Tal perspectiva leva à criação de diversos tipos de paisagens como apresentado.

$\mathrm{Na}$ atualidade a mineração é essencial para a vida dos seres humanos, pois é a partir dela que se tem elementos para produção de praticamente todos os elementos não naturais consumidos. Apesar dessa realidade, existe um movimento forte contra a mineração, como algo que não deve ser tolerado no atual estado de proteção ambiental. O mesmo se diz das minas após o fim das atividades. São vistas como elementos a serem escondidos, recobertos. Tal perspectiva pode ser interessante, mas, para além disso, deve-se considerar o que a sociedade, que tanto tempo viveu da mineração e do entorno dela - já que os projetos de mineração são de médio a longo prazo - pensa e como se sente a respeito do tema.

A paisagem, seu reconhecimento e sua proteção são democráticos e por sua representatividade social não é sustentável que externamente seja imposto a uma sociedade a mudança sem que seja ouvida.

A participação inicia-se com a educação para a paisagem, raiz que planta na sociedade o interesse em participar, em opinar e principalmente compreender o papel da mineração em suas vidas, seja ele positivo ou negativo. A mobilidade é algo natural numa paisagem e deve ser considerada quando da tomada de decisões que devem ser realizadas pela comunidade já consciente de sua paisagem, em conjunto com os órgãos públicos e com o empreendedor, considerando assim todos os lados e perspectivas de impactos, seja na natureza, cultura e patrimônio, que no fim configuram a paisagem em si, tanto para a abertura quanto para o fechamento de minas, cumprindo efetivamente o papel social da empresa para com a sociedade. Assim, essas decisões constroem o produto ideal que aquela sociedade 
pretende legar para as futuras gerações. $\mathrm{O}$ fechamento da mina já produz um trauma grande na sociedade, pois, quando ocorre deixa um rastro e

[...] mostra que todos têm de enfrentar os mesmos desafios na superação dos efeitos negativos da cessação ou redução do tamanho das atividades de mineração. Os problemas enfrentados são o alto desemprego, baixas taxas de PIB e desenvolvimentos demográficos negativos (especialmente a emigração de pessoas mais jovens e qualificadas). Esses problemas tendem a ocorrer em graus variados, dependendo do caminho de desenvolvimento adotado por cada região e condições estruturais nacionais e locais específicas (WIRTH; ČERNIČ; FISCHER, 2012, p. 39, tradução nossa).

Ao pensar no processo de recuperação, mais que considerar apenas o elemento natural, deve-se considerar como aquela sociedade se relaciona com a mina, como dito muitas vezes, a mina está entrelaçada com a cultura e história daquela região e não se pode simplesmente apagá-la da memória, apenas para garantir um único elemento do meio ambiente, o natural.

Deve-se considerar que a existência da mina passa a compor a existência dos indivíduos de entorno e por isso estes devem participar das decisões de qual destinação ela deve ter, pois muitas vezes apenas a correção da natureza de forma artificial não atende aos interesses sociais. Assim, é preciso abrir-se para outras ideias, como a criação de áreas de lazer, shows, manutenção da paisagem da mina como representação histórica da sociedade, turismo, ou mesmo a recuperação ambiental. Mantendo assim viva a memória de um elemento que participou da sociedade por tanto tempo, estando enraizada no que é ser membro daquela sociedade e, portanto, deveria continuar a participar de alguma maneira.

A comunidade mineira expressa sua cultura em estruturas sociais específicas, uma situação financeira relativamente boa, um forte senso de união, orgulho e comportamento introvertido. As tradições dos mineiros são, portanto, muito distintas e alienígenas, até mesmo misteriosas para os estrangeiros. Para explorar o mundo da mineração e mineiros, sua herança cultural como manifestada nos "produtos artificiais da mineração", seja material, como edifícios e infraestruturas, ou imateriais, como as tradições do mineiro, pode, portanto, interessar tanto aos mineiros como ao público em geral. Um segundo elemento no potencial cultural é a mineração de edifícios e infraestrutura de mineração. Algumas dessas relíquias de atividades de mineração foram revitalizadas como museus, pois um elemento dos potenciais culturais é a tradição. Ela se manifesta, por exemplo, nos costumes e observâncias (por exemplo, "Dia dos Mineiros") cultivadas mesmo após a cessação da mineração (WIRTH; ČERNIČ; FISCHER, 2012, p. 24, tradução nossa). 
As indústrias de mineração têm desempenhado um papel crucial na história europeia, sendo um importante fator de desenvolvimento econômico e social ao longo dos séculos. Sem a extração de matérias-primas, como cobre, ferro, prata, sal e carvão, a trajetória de desenvolvimento do continente seria distintamente diferente (WIRTH; ČERNIČ; FISCHER, 2012). E a sociedade seria diferente, por isso ao implementar um projeto de estruturação econômica que proteja a sociedade e suas paisagens, Wirth, Černič e Fischer (2012) trazem como elementos que efetivam a governança e a participação democrática: a analise de viabilidade para o local indicado, a sustentabilidade, a transparência, abertura e envolvimento dos atores sociais, a legitimidade, a inovação e, se replicado de um outro contexto, que seja possível transpor para o local que será aplicado.

Nessa perspectiva. alguns processos de sucesso foram realizados no mundo. Como forma de exemplificar, analisar-se-ão três casos emblemáticos e que se assemelham à realidade de Minas Gerais. Neles, a cultura mineira e os elementos mantiveram-se após o fechamento da mina, de forma a garantir a interligação social com seu meio e que os membros da comunidade se sintam orgulhosos de seu passado, desejando perpetuar a cultura que construíram às futuras gerações, sempre com a mutabilidade inerente à paisagem, mas numa linha continua de construção como projeto social, sem quebras que retirem do sujeito seu passado para construir o futuro.

\section{FECHAMENTO DE MINAS E A PAISAGEM: UMA REALIDADE PARA ALÉM DA RECOMPOSIÇÃO AMBIENTAL}

Como apresentado a mineração faz parte da vida de muitas comunidades e quando de seu fim, deve ser considerada não apenas a perspectiva ambiental, mas também a de paisagem ao dar função aquele território onde a mineração deixou de existir. Segundo Wirth, Černič e Fischer (2012), a mineração exerceu um papel essencial na história europeia ajudando a realizar desenvolvimento social e econômico há muitos séculos. E pode-se dizer o mesmo do Brasil, em especial do Estado de Minas Gerais.

A mineração é uma paisagem industrial e "La industrialización y los testimonios de la historia social y de la técnica, han dejado de ser una rémora y se han convertido en recursos para el desarrollo local, con fines culturales y turístico (LÓPEZ; MACÍAS, 2008, p. 84). E hoje a industrialização e suas formas de realização fazem parte da história humana, merecendo assim proteção, como qualquer outro patrimônio cultural, assim, "está 
reconocida la importancia que para el estudio de las sociedades modernas tiene el patrimonio industrial que fue generado con las actividades de transformación y explotación de los sectores productivos, sobre todo a partir de la revolución industrial" (LÓPEZ; MACÍAS, 2008, p. 84). Esta constrói, por meio de seus elementos, a paisagem industrial que, segundo Lopéz e Macías (2008, p. 84), é constituída

[...] por un conjunto de elementos que transmiten la complejidad y la profundidad del impacto industrial tanto físico como social en una comunidad. [...] La visión sobre el patrimonio debe ser flexible y dinámica, ya que queremos identificaren ella al conjunto de elementos y prácticas sociales a través de los cuales un colectivo pretende reconocerse y representarse.

A manutenção dessa paisagem utilizando-a para o turismo de vários tipos ou outro aproveitamento é uma das formas de desenvolvimento sustentável no local, pois amplia a oferta de vagas de trabalho, ocupando o lugar de outros setores vinculados à mineração que vão degenerando devido ao fechamento da mina.

Demonstrando a possibilidade de tal fato, serão apresentados três casos emblemáticos como exemplos de possiblidades de um meio termo entre recomposição ambiental e proteção da paisagem. Sendo os casos de Bassin Minier, Nord-Pas-de-Calais, na França, Mansfeld-Südharz na Alemanha e Minerias Del Rio Tinto, Huelva, Espanha.

\subsection{Bassin Minier, Nord-Pas-de-Calais, França}

A Bassin Minier (Bacia de Mineração) de Nord-Pas-de-Calais, na França, está localizada no centro de uma área de grande desenvolvimento comercial e um importante cruzamento de comunicação entre as principais cidades europeias (ABAD, 2016), logo sua localização geográfica era perfeita para extração e transporte eficiente do minério. Bem como sua especificidade de ser um o único grande depósito de carvão inteiramente subterrâneo: com 120 quilômetros de extensão; 12 quilômetros de largura; 1,2 quilômetros de profundidade (BASSIN MINIER PATRIMOINE MONDIAL, 2019).

A história de Bassin Minier começa com a descoberta do carvão em 1720, por Jacques Desandrouin. Mas a primeira empresa de mineração, a Anzin Mining Company, é fundada em 1757. Sua exploração foi motor para a primeira revolução industrial na década de 1830, tendo seu auge, um século após, na década de 1930 (FONDATION DU PATRIMOINE, 2018). 
Em 1946, por lei, torna-se propriedade do Estado e passa a ser administrada pela Houillères da Bacia Nord-Pas-de-Calais (HBNPC), passando em 1948 por uma grande modernização de suas instalações. A Bassin Minier foi crucial para a reconstrução da França pós-segunda guerra mundial, nos chamados "trinta anos gloriosos" (1945-1973) (BASSIN MINIER PATRIMOINE MONDIAL, 2019, p. 19).

Em 1960, o plano Jeannenney inicia o processo de declínio do ciclo do carvão, sendo que em 1990 a produção de carvão é encerrada na área. Com a exaustão das minas, inicia-se a demolição dos equipamentos de mineração de Bassin Minier e com ela surge e cresce a consciência da importância daqueles patrimônios e daquela paisagem industrial. Inicia-se a proteção de alguns elementos, dentre eles as pilhas de rejeitos remanescentes, dentre os quais alguns passam a ser protegidos contra uso. Inicia-se o reconhecimento de Bassin Minier como representação de três séculos da história industrial - onde foram acolhidas populações de 29 nacionalidades distintas, de paisagens criadas, culturas e modos de vida (BASSIN MINIER PATRIMOINE MONDIAL, 2019, p. 21).

Em 2 de julho de 1996 foi criada por lei a Fundação do Patrimônio que em 1997 foi reconhecida como de utilidade pública. Ela é composta de 22 delegações regionais e tem uma rede de 560 voluntários que trabalham na conservação do patrimônio. Ela apoiou desde sua criação 27 mil projetos públicos e privados para garantir o desenvolvimento sustentável da região, contribuindo para a criação de emprego, integração profissional e formação de jovens (FONDATION DU PATRIMOINE, 2018).

Com a proteção, em Bassin Minier, as pilhas de rejeitos, passam a ser símbolo de resiliência do território e testemunho da história, e para garantir de sua proteção passa ter uma série de novos usos. As antigas áreas de extração de carvão tornam-se áreas de prática de esportes, espaços para educação, cultura e lazer, inclusive aproveitamento de estruturas para musicais, peças teatrais e laboratório de pesquisa de museu de mina (FONDATION DU PATRIMOINE, 2018). As pilhas de rejeitos protegidas tornam-se as atrações turísticas principais, uma singularidade do território que se mistura à paisagem preexistente, mas, ao mesmo tempo, assume sua artificialidade, tornando-se o símbolo dessa paisagem, que, segundo, o site Bassin Minier Patrimoine Mondial (2019, tradução nossa):

Eles constituem vetores imediatos e particularmente poderosos de emoções, que desafiam nossos olhos, e nos questionam com força sobre a atividade de mineração, 
extinta e, no entanto, tão presente por esses traços monumentais que ela legou. A monumentalidade de certas escórias empilha sua percepção a grandes distâncias.

Em menor número e menores que as pilhas de rejeitos, as 21 torres dos antigos elevadores de minas têm sua importância reconhecida graças a sua associação às entradas subterrâneas da mina e como testemunhas da evolução das técnicas construtivas e de extração e, em função de sua altura, acabaram tornando-se mirantes de observação da paisagem (BASSIN MINIER PATRIMOINE MONDIAL, 2019).

Bassin Minier tem, ainda, 68.000 habitações mineiras de diversidade arquitetônica construídas em bairros com grande qualidade urbana e fornecimento de equipamentos públicos (escolas, postos de saúde, etc.) necessários à vida cotidiana. Há também ressurgimento de elementos naturais nas antigas áreas de mineração, criando áreas de vazios e verdadeiros oásis na zona muito urbanizada de Nord-Pas-de-Calais, ou manutenção de áreas que lembram paisagens lunares.

Com o processo de busca de reconhecimento como patrimônio mundial iniciado em 2000, Bassin Minier recebe em 2012 o título de "Paisagem cultural evolutiva viva" composta por 3.563 elementos indissociáveis (FONDATION DU PATRIMOINE, 2018).

Em 2012, na cidade de Lens, região de Nord-Pas-de-Calais, com projeto integrado à paisagem minerária, foi inaugurada uma unidade do museu do Louvre para exposição de parte de seu acervo. Atualmente se estuda a implementação de parque de energia eólica na região, mas ainda tem que ser analisado o impacto das turbinas na paisagem industrial mineira protegida. Assim, a paisagem modifica-se junto com a sociedade, sem perder seu vínculo com o passado mineiro que representa.

\subsection{Mansfeld-Südharz na Alemanha ${ }^{3}$}

Mansfeld-Südharzé uma região que se localiza entre Frankfurt e Berlim e pertenceu à Alemanha Oriental. Essa região tem uma tradição de mineração de mais de 1.000 anos, e já foi uma das mais importantes do mundo, segundo Jankowski (1995 apud HARFST; WIRTH, 2012). O extrato mineral mais importante da região foi o cobre, minerado de 1200 a 1990. Segundo dados de Harfst e Wirth (2012) mais de 50 milhões de metros cúbicos desse material foram escavados e tiveram que ser extraídos pela mineração.

3 Os dados desse caso foram retirados da pesquisa de Harfst e Wirth (2012). Para mais informações, acessar o livro, disponível online gratuitamente (vide lista de referências). 
Com a queda do muro de Berlim e a mudança de regime da Alemanha Oriental, que em 1990 se junta à Alemanha Ocidental, formando um só país sob a política governamental da segunda, a mineração realizada na região é finalizada por não ser lucrativa. Pincipalmente por causa do beneficiamento, a mineração deixa um passivo ambiental enorme com áreas contaminadas por metais pesados oriundos de resíduos sólidos e efluentes líquidos. Muitos resíduos inertes foram utilizados na base para pavimentação de estradas, mas várias áreas ainda apresentam grandes depósitos de resíduos em pilhas em forma de cone, que se tornaram característicos da região como marcos de um passado mineiro.

Com o fim da mineração, tem-se o quadro comum que ocorre em qualquer parte do mundo com regiões totalmente dependentes da atividade: desemprego e emigração dos mais jovens e qualificados. Para agravar o problema, em 1994 a única instituição de ensino superior da região, a Escola de Engenharia de Minas, fecha suas portas, provocando um retrocesso ainda maior na região, pois dificulta a construção de redes para explorar o patrimônio pós-mineração ou mesmo para iniciar novas atividades (HARFST; WIRTH, 2012).

Devido a todas essas dificuldades a região tem recebido financiamento estatal para vários projetos como os de áreas rurais, pequenas e médias empresas e infraestruturas de turismo. O financiamento é gerido por um grupo com representação das associações oficiais de mineradores, que se demonstrou mais preocupado com a conservação do patrimônio da mineração e manutenção da paisagem industrial, com fins turísticos e de sensibilização local. A região, para implementar o turismo, tem outro elemento importante, Martinho Lutero, o líder da Reforma Protestante, que ali viveu e morreu - na cidade de Eisleben - e que teve como pai um minerador. As ligações com essa figura histórica trazem um potencial turístico inicial por ser a marca da região de Mansfeld, e pode ser o começo para incrementar o turismo de mineração como forma de preservação dos processos que possibilitaram a industrialização da região e que se tornaram sua tradição. Assim projetos desenvolveram o turismo voltado para o patrimônio minerário. Um número extenso virtual de dados foi criado para informação dos projetos turísticos da região, fomentando a atividade. Foram criados 13 museus e um especialmente voltado para a história da mineração, com materiais vindos da fechada Escola de mineração em Eiseben que foi criada em 1798. A ferrovia também foi recuperada, tudo buscando desenvolver o potencial turístico da região e recuperar sua identidade mineradora, as 
tradições e o orgulho da comunidade. Além do patrimônio cultural responsável pela paisagem industrial, várias áreas verdes foram recuperadas e ainda foram utilizados os potenciais pós-mineração como aproveitamento de energia geotérmica.

A recuperação econômica da região não foi e não tem sido fácil, mas os projetos têm sido bem-sucedidos e mantêm a paisagem e o respeito à tradição da região e aos vínculos dos atores regionais.

\subsection{Minerías Del Rio Tinto, Huelva, Espanha}

A região de Minerías del Rio tinto fica em Huelva na Andaluzia, sul da Espanha, e, de uma perspectiva etnológica, foi a região onde mais desenvolveu a cultura minerária, mostrando-se representativa na Espanha, e foi a precursora do desenvolvimento econômico e industrial de Huelva (LÓPEZ; MACÍAS, 2008).

Pelas características geomorfológicas e bioclimáticas a paisagem original da região era formada por baixo relevo e alta altitude, coberta com vegetação tipicamente mediterrânea. Mas, com a prática de milênios de mineração, a paisagem foi moldada, transformando radicalmente o território e seus elementos (GHISLANZONI; DACAL, 2014).

Historicamente, a mineração na região iniciou-se 5.000 anos atrás, ainda na Idade do Cobre, e manteve-se até a atualidade. No mundo antigo, era uma das regiões minerárias mais importantes do mundo conhecido, e por isso sua história é excepcional. Ela demonstra um panorama mais completo da evolução das técnicas minerárias e metalúrgicas (GHISLANZONI; DACAL, 2014; ABAD, 2016).

O primeiro grande período de exploração deu-se na era da Roma Antiga, a partir de 206 a.C., onde os romanos se dedicavam, principalmente, à extração de prata na região e deixaram toda a expressão de uma época com necrópoles, rede de estradas dentre outros. Já na época Medieval, a exploração foi reduzida voltando a ser uma produção familiar e na época Islâmica a produção era principalmente de elementos para fabricação de corantes. A retomada da produção na modernidade ocorre no século XVIII, mas as minas eram sempre cedidas a estrangeiros que buscavam lucro rápido, até ser finalmente assumida em 1873, pela empresa inglesa Rio Tinto Limited Company que a geriu até 1954 (GHISLANZONI; DACAL, 2014). Como toda mineração extensiva causou enormes danos ambientais (FERNÁNDEZ-CALIANI; GALÁN, 1996; VAN GEEN et al., 1997 
apud GONZÁLEZ et al., 2012) e paisagísticos como exemplifica a mina de Corta Atalaya que foi aberta em 1907 e chegou a ser a maior mina a céu aberto. $\mathrm{O}$ uso da área foi explorado de forma extensiva de forma que muitas vezes mudou até cidades inteiras para realizar a mineração, como aconteceu com Rio Tinto, causando uma mudança de cultura e relação com a própria paisagem. A recuperação ambiental não foi efetivada na região pois a empresa encerra suas atividades antes da RDL1302/86 que obriga a recuperação ambiental (GONZÁLEZ et al., 2012). As modificações foram tantas e tão expressivas em todos os elementos naturais, artificiais e urbanísticos; e com vários estágios que o governo da Andaluzia declarou parte da área de mineração como paisagem protegida (BOJA 10/2005, de 17 de janeiro) (GONZÁLEZ et al., 2012; ABAD, 2016).

A exploração parou totalmente em 2001 devido ao baixo preço do material que era extraído, sendo que partiu da própria empresa a criação do Parque Minerário de Rio Tinto, criando em 1987 criou a Fundação Rio Tinto, que começou a desenvolver o projeto turístico na área, recuperando elementos patrimoniais, apoiando a manutenção do ambiente modificado, a abertura de museus e a reabilitação da linha férrea, para fins turísticos, com a restauração das locomotivas. Mas ao contrário de outras zonas minerárias não fizeram a recuperação natural, mantendo a paisagem transformada como atrativo estético. Mantendo assim as minas a céu aberto, como foram deixadas como elementos mais expressivos da paisagem protegida e reconhecida, bem como pilhas de estéreis e águas ácidas - vendidas como souvenir aos turistas (ABAD, 2016). Foi zoneada a área a ser protegida de forma a destacar a ação minerária em todas as suas etapas, formando uma paisagem única que foi protegida em 2005 como sitio histórico pela Ley de Patrimonio Histórico Andaluz de 1991 (ABAD, 2016). Mas ao mesmo tempo, considerando o conceito europeu de paisagem, sem museificá-la, mas garantindo sua conservação e função sem impedir seu desenvolvimento e evolução (GHISLANZONI; DACAL, 2014). Minerias del Rio Tinto é um dos casos de maior sucesso em termos de manutenção da paisagem reconhecida pela sociedade, reinserção econômica da região e representatividade da paisagem industrial minerária.

\section{MINAS GERAIS, MINERAÇÃO E PERTENCIMENTO}

A mineração é o fio que conduz a história e a formação do Estado de Minas Gerais. No período Colonial, a partir de 1690, já havia centenas de 
lavras de ouro aluvionar na Região Central do Estado. De 1700 a 1780, Minas Gerais produziu mais da metade do ouro e boa parte das gemas e diamantes extraídos no Brasil. Essa produção mineral fomentou a abertura de estradas, como por exemplo, a Estrada Real, a criação de uma estrutura administrativa própria e a implantação de núcleos urbanos que conduziram e possibilitaram a unificação do território. Cidades como Ouro Preto, Congonhas, Sabará, São João Del Rei, Tiradentes, Diamantina, Serro e várias outras prosperaram em torno das minas. Entre 1700 e 1808 a população mineira cresceu 10 vezes o número inicial de 30 mil habitantes. Com a independência de Portugal, seis empresas inglesas assumiram a extração de ouro na região, dentre elas a St. John Del Rey Mining Company. Com a exploração do ouro, foram encontradas áreas de minério de ferro, ainda na primeira metade do século. XIX que fomentaria a inicial e incipiente indústria brasileira. Em 1814 foram instalados os primeiros altos-fornos de ferro gusa na fábrica em Morro do Pilar e, em 1825, João Monlevade instalou outra fábrica em São Miguel do Piracicaba, cidade que hoje leva seu nome. Outro fator importante para o desenvolvimento técnico da atividade no Estado, foi a criação da Escola de Minas em Ouro Preto em 1876 (ALVES, 2008).

Em 1894, iniciou-se a exploração de manganês no Morro da Mina, em Conselheiro Lafaiete. No início do século XX, foi formada a Itabira Iron Ore Corporation, empresa inglesa que adquiriu os direitos das minas de ferro de Itabira e participação na estrada de ferro Vitória-Minas. Em 1940, os direitos das minas de Itabira foram transferidos para o governo brasileiro e, dois anos depois, foi constituída a Companhia Vale do Rio Doce. A década de1960 foi marcada pela abertura do setor mineral brasileiro ao capital estrangeiro. Nesse contexto, surgiram as empresas MBR, Samitri, Ferteco, Alcoa, CBMM e Usiminas, entre outras (ALVES, 2008, p. 30).

De acordo com os dados do DNPM, hoje Agência nacional de Mineração (ANM) em 2014, no estado de Minas Gerais, haviam $258.610,7 \mathrm{~km}^{2}$ de áreas (44,09\% do estado) em alguma fase de concessão para mineradoras, sendo que, desses, $64.530,62$ (11,00\% do estado) já tinham sido concedidos ou liberados. No total foram registrados 40.614 empreendimentos, desses o maior número $(4.908 ; 12,08 \%)$ são de minério de ferro (REZENDE, 2016).

Com as tragédias ocorridas em Bento Rodrigues, distrito de Mariana em 2017 e em Brumadinho em 2019, as discussões sobre a mineração que nunca deixaram de existir, voltam a ser centro de atenção. E a mineração 
expõe sua face mais visível da degradação ambiental com mais força, sendo desqualificada e vista como um problema a ser resolvido.

Entretanto, as tragédias só representam uma perspectiva da mineração, que reforçam a forma de percepção geral da sociedade mineira de que a mineração é algo ruim a ser desmantelado e suas marcas apagadas.

Todavia, há que se considerar que a recuperação ambiental prevista no $\S 2^{\circ}$ do art. 225 da Constituição Federal: "Aquele que explorar recursos minerais fica obrigado a recuperar o meio ambiente degradado, de acordo com solução técnica exigida pelo órgão público competente, na forma da lei” (BRASIL, 1988), deixa em aberto as soluções técnicas para a decisão dos órgãos ambientais competentes.

Nesse aspecto, a Fundação Estadual do meio Ambiente (FEAM), inspirada no movimento internacional Mine Closure, que prevê os diversos usos para a recuperação de minas exauridas, propôs ao Conselho Estadual de Política Ambiental (COPAM) novos conceitos para a recuperação ambiental de minas exauridas, que foram consubstanciados na Deliberação Normativa (DN) COPAM n. 127/2008, que dentre outros estabelece que o uso futuro da área minerada levará em conta "as suas aptidões, a intenção de uso pós-operacional, as características dos meios físico e biótico e os aspectos socioeconômicos da região", o que significa que não necessariamente seria a alternativa convencional de revegetar toda a área (MINAS GERAIS, 2008). A atualização dessa norma, pela DN COPAM n. 220/2018, manteve esse conceito (MINAS GERAIS, 2018).

Com tanto tempo de exploração e tendo inclusive seu nome vinculado à mineração, a preocupação com o fechamento de minas nas diversas cidades que hoje dependem dela para sua existência no Estado de Minas Gerais, é cada vez mais presente. Segundo o Instituto Brasileiro de Mineração (IBRAM) a mineração em Minas Gerais representa 12\% de seu PIB, sendo que em alguns municípios mineiros, a mineração representa direta e indiretamente mais de 50\% da receita (CILO, 2019). O fechamento e a desativação de minas aparecem como um problema a ser solucionado de forma a reduzir os impactos esperados como já vistos - desemprego, retração econômica, emigração especialmente de jovens, etc. - e suas marcas ignoradas. Essa questão aparece de forma bem significativa em Nova Lima que já teve uma mina fechada e em Itabira, que em médio prazo, terá o fim das reservas de ferro no município e com ele o fim da mineração. 
Ao ver as soluções que vêm sendo implementadas para a recuperação de áreas mineradas é impressionante como a paisagem e o vínculo da sociedade são absolutamente ignorados, é como se a mineração fosse um inimigo finalmente extirpado da sociedade que se deve esquecer. Mesmo para apostas vantajosas para atividades pós-mina como novas tecnologias e inovações digitais, a questão que se coloca é que uma sociedade vinculada a mineração por mais de um século não deveria ignorar seu passado olhando apenas o futuro pois gera um desvincular social onde o cidadão comum não se enxerga mais parte daquele meio. É necessário trabalhar junto à população para ligar esse passado e sua passagem para o futuro de forma a não ignorar o pertencimento da sociedade a sua região. As soluções devem ser democráticas com a participação de todos os segmentos sociais de forma a garantir sua inserção profissional, mas, principalmente, sua inserção como membro de uma sociedade minerária que alavancou o crescimento econômico e industrial da região e do país, demonstrando a importância, as tradições criadas entorno da mineração e seu orgulho pelo trabalho realizado de forma a preservar essa paisagem criada que representa a comunidade.

As regiões minerárias de Minas Gerais não são tão diferentes de Bassin Minier e outras do mundo que não poderia considerar a inserção econômica no futuro sem olvidar do passado.

Itabira é um caso emblemático no Estado e que muito se assemelha a Mansfeld-Südharz. Conhecida como a "cidade do Ferro" é o local de origem da Companhia Vale do Rio Doce, atualmente Vale, dependendo economicamente ainda da produção do ferro com duração prevista no máximo de 50 anos, já começa a buscar alternativas para a mudança. A lógica inicial é apostar no segmento tecnológico, mas como Mansfeld ela tem um símbolo importante Carlos Drummond de Andrade, grande poeta brasileiro, reconhecido internacionalmente, que nasceu em Itabira e tem raízes vinculadas à mineração. $\mathrm{O}$ turismo poderia iniciar com a construção turística em torno do poeta, mas poderia também encaminhar para um turismo de mineração industrial, já que a cidade perpassou mais de um século de explorações e técnicas utilizadas para realizar a mineração. A cidade tem as marcas da mineração, crateras enormes e áreas onde a mineração ocorria, podendo usar isso como ponto para criação de turismo minerário, interligar com artes ou mesmo propiciar um espaço para esportes ou um vazio verde para deleite social de forma que não se percam os laços com a atividade que forjou a sociedade itabirana de hoje. 
A mineração sempre foi atividade essencial ao crescimento socioeconômico de Minas Gerais, pois além de forjar a própria origem do estado, forjou diversas cidades e paisagens mineiras que precisam ser reconhecidas e respeitadas. Essa perspectiva deve iniciar-se com o levantamento da história das regiões minerárias, o patrimônio, realizar educação paisagística para que as sociedades vejam sua ligação profunda com a mineração e protejam essas paisagens. Para além das montanhas, a paisagem industrial da mineração merece proteção por tudo que significou e significa para o Estado e a sociedade, bem como para as municipalidades e as comunidades que dela dependeram e construíram tradições e valores que devem ser resguardados como representação cultural de um povo.

\section{CONCLUSÃO}

A paisagem é a interseção entre a sociedade e o meio que construiu, sendo representação cultural desta e mutante como ela.

Com a afirmação do Estado democrático de direito, a paisagem perde sua caracterização necessária de ser um elemento natural e passa a ser um projeto coletivo, logo com participação social. A paisagem tem a função de garantir pertencimento e coletividade numa comunidade local, regional, nacional ou mundial. E é composta por três elementos: o espacial, o humano e o subjetivo.

A paisagem minerária, enquanto paisagem industrial busca garantir todas as funções e tem composição como qualquer outra paisagem. Ela é a representatividade da história da industrialização e deve ser protegida por sua importância para a sociedade passada e fazer o liame desta com as gerações futuras, sendo palco de tradições e motivo de orgulho das raízes da comunidade efetivando o eterno pertencimento social necessário.

Foram analisados os casos de Bassin Minier, Nord-Pas-de-Calais, na França, Mansfeld-Südharz na Alemanha e Minerias Del Rio Tinto, Huelva, Espanha como forma de demonstrar que mesmo com o fim da exploração mineral é possível o desenvolvimento econômico com apoio na mineração, efetivando o desenvolvimento social elemento essencial do desenvolvimento sustentável.

Minas Gerais é a região emblemática brasileira quando se fala em mineração, por ser a atividade que forjou a formação do próprio estado e muito contribuiu para a promoção de seu desenvolvimento socioeconômico. Entretanto, tenta apartar-se desse elemento histórico essencial no forjar do 
mineiro sem ao menos entender sua representatividade ou papel social. Isso, especialmente, após as tragédias recentes de Bento Rodrigues e Brumadinho.

É necessário efetivar a educação paisagística e o levantamento do patrimônio cultural da mineração no Estado de forma que se proteja a paisagem minerária mineira, representante da história e que forjou a sociedade mineira de forma a garantir seu pertencimento e formação coletiva. É preciso alavancar o orgulho do passado que os representa e transmitir esse orgulho às gerações futuras de forma a construir uma paisagem que realmente representa Minas Gerais

Só assim, a sociedade mineira será uma verdadeira comunidade preocupada em estabelecer uma democracia real e participativa onde se reconhecem a identidade e o pertencimento.

Nesse momento posterior a casos de tragédias com barragens de mineração em Minas Gerais - Bento Rodrigues e Brumadinho -, as mineradoras iniciam um processo de descomissionamento dessas barragens para evitar novas tragédias, causadas por técnicas obsoletas com alteamento a montante, que já deveriam estar proibidas há muito tempo e só recentemente foram proibidas em Minas Gerais pela Lei Estadual n. 23.291, de 26 de fevereiro de 2019.

O exaurimento de minas deve ser pensado de forma a não haver uma quebra na cultura minerária existente nas cidades onde a mineração se desenvolveu e está enraizada na cultura social. A proteção e recomposição ambiental são muito importantes e indiscutíveis, entretanto, a proteção da paisagem também o é, e ambos têm status de proteção constitucional e devem ser consideradas de forma equânime.

Numa sociedade democrática é necessário ser pensado que ela deve participar das decisões, não cabendo mais defender que apenas a administração pública ou técnicos sabem o que é melhor para a comunidade, membros da sociedade tem que participar das decisões, sob pena de não se efetivarem a democracia, a proteção cultural, a proteção da própria sociedade.

Nos casos apresentados, há exemplos de que, sim, é possível compatibilizar paisagem e proteção ambiental. E são exemplos que podem inspirar como realizar essa compatibilização na nossa realidade, cumprindo o preceito de garantia de direitos humanos e desenvolvimento sustentável de cada comunidade de forma democrática. 


\section{REFERÊNCIAS}

ABAD, C. J. P. El Paisaje minero-industrial de Riotinto (Huelva). Proyecto Redes 2015-2016, 2 abr. 2016. Disponível em: <https://www2. uned.es/culturpaisgrupo/images/03_CULTURPAIS_Redes\%20201516_PAISAJE\%20MINERO\%20INDUSTRIAL\%20DE\%20RIOTINTO_ Carlos\%20Pardo.pdf>. Acesso em: 20 jul. 2019.

ALVES, A. N. Histórico e importância da mineração no estado. Revista do Legislativo, Belo Horizonte, n. 41, p. 27-32, jan./dez. 2008. Disponível em: <https://www.almg.gov.br/export/sites/default/consulte/ publicacoes_assembleia/periodicas/revistas/arquivos/pdfs/41/historico_ importancia_41.pdf $>$. Acesso em: 20 jul. 2019.

BASSIN MINIER PATRIMOINE MONDIAL. Trois siècles d'histoire. Disponível em: <http://www.bassinminier-patrimoinemondial.org/troissiecles-dhistoire/>. Acesso em: 20 jul. 2019.

BRASIL. Decreto-Lei $n$. 25, de 30 de novembro de 1937. Organiza a proteção do patrimônio histórico e artístico nacional. Rio de Janeiro: Presidência da República, 1937. Disponível em: <http://www.planalto. gov.br/ccivil_03/decreto-lei/del0025.htm>. Acesso em: 20 jul. 2019.

BRASIL. Constituição da República Federativa do Brasil de 1988. Brasília, DF: Presidência da República, 1988. Disponível em: <http:// ww.planalto.gov.br/ccivil_03/constituicao/constituicao.htm>. Acesso em: 20 jul. 2019.

CILO, N. Sem mineração, PIB de Minas pode encolher $12 \%$, diz estudo. Estado de Minas, 10 maio 2019. Disponível em: <https://www.em.com. br/app/noticia/economia/2019/05/10/internas_economia,1052625/semmineracao-pib-de-minas-pode-encolher-12-diz-estudo.shtml $>$. Acesso em: 20 jul. 2019.

CUSTÓDIO, M. M. Introdução ao Direito de Paisagem: contribuições ao seu reconhecimento como ciência no Brasil. Rio de Janeiro: Lumen Juris, 2014.

DONADIEU, P.; PERIGORD, M. Clés pour le Paysage. Paris: Geophrys, 2005. 
FONDATION DU PATRIMOINE. Patrimoine minier en danger. Dossier de presse, 26 jun. 2018. Disponível em: $<$ https://www.fondation-patrimoine. org/les-projets/patrimoine-minier-en-danger>. Acesso em: 20 jul. 2019.

FORTIN, M.-J. Le paysage, cadre d'évaluation pour une société réflexive. Saguenay: Université du Québec à Chicoutimi, 2003. Disponível em: $<$ www.symposcience.fr/exl-doc/colloque/ART-00001210.pdf $>$. Acesso em: 5 abr. 2019.

GHISLANZONI, M.; DACAL, M. R. La Zona Patrimonial de la Cuenca Minera de Riotinto-Nerva como modelo de protección de un paisaje cultural. In: VII CONGRESO INTERNACIONAL DE ORDENACIÓN DEL TERRITORIO, 7., 2014, Madrid. Anales [...]. Madrid: Fundicot, 2014. p. 1-15. Disponível em <https://www.researchgate.net/ publication/279574925_La_Zona_Patrimonial_de_la_Cuenca_Minera_ de_Riotinto-Nerva_como_modelo_de_proteccion_de_un_paisaje_ cultural>. Acesso em: 20 jul. 2019.

GONZÁLEZ, I. et al. Patrimonio natural antropizado del area minera de Río Tinto (España). In: I CONGRESO INTERNACIONAL "EL PATRIMONIO CULTURAL Y NATURAL COMO MOTOR DE DESARROLLO: INVESTIGACIÓN E INNOVACIÓN", 1., 2011, Sevilla. Anales [...]. Sevilla: UNIA, 2012. p. 1361-1380. Disponível em: $<$ https:// idus.us.es/xmlui/bitstream/handle/11441/76567/galan_patrimonio. pdf? sequence=1\&isAllowed=y>. Acesso em: 20 jul. 2019.

HARFST, J.; WIRTH,P. M.-S. From industrial heartland. In: WIRTH, Peter. ČERNIČ, B. M. FISCHER W. (Editors). Post-mining regions in Central Europe: problems, potentials, possibilities. München: oekom. 2012. p. 53-62. Disponível em: <https://www.ioer.de/fileadmin/internet/ IOER_Projekte/PDF/FB_L/Book_Publication_Post-Mining_Regions_in Central_Europe.pdf $>$. Acesso em: 20 jul. 2019.

IPHAN - INSTITUTO DO PATRIMÔNIO HISTÓRICO E ARTÍSTICO NACIONAL. Paisagem cultural. Brasília, DF: Depam/Iphan, 2009. Disponível em: <http://portal.iphan.gov.br/uploads/ckfinder/arquivos/ Livreto_paisagem_cultural.pdf $>$. Acesso em: 30 mar. 2019.

LAMEGO, V. et al. A mineração na Primeira República. In: Vale: nossa história 2012. Rio de janeiro: Verso Brasil, 2012. p. 16-37. Disponível em: 
$<$ http://www.vale.com/PT/aboutvale/book-our-history/Documents/livro/ Vale_Livro_Nossa_Historia_cap1.pdf $>$. Acesso em: 20 jul. 2019.

LÓPEZ, J. M. P.; MACÍAS, E. M. R. Actuaciones sobre el patrimonio minero-industrial de la provincia de Huelva: Cuenca minera de Riotinto. PASOS-Revista de Turismo y Patrimonio Cultural, Santa Cruz de Tenerife, v. 6, n. 1, p. 83-96, 2008. Disponível em: <http://www.pasosonline.org/ Publicados/6108/PS0108_7.pdf >. Acesso em: 20 jul. 2019.

MARCEL, O. et al. (Dir.). Paysage modes d'emploi: pour une histoire des cultures de l'aménagement, les cahiers de la compagnie du paysage. n. 4 , Seyssel: Champ Vallon, 2006.

MEIRELLES, H. L. Direito Administrativo Brasileiro. 26. ed. São Paulo: Malheiros, 2001.

MINAS GERAIS. Secretaria de Estado de Meio Ambiente e Desenvolvimento Sustentável. Conselho Estadual de Política Ambiental. Deliberação Normativa (DN) COPAM n. 127, de 27 de novembro de 2008. Estabelece diretrizes e procedimentos para avaliação ambiental da fase de fechamento de mina. (revogado). Belo Horizonte: COPAM, 2008. Disponível em: <http://www.siam.mg.gov.br/sla/download. pdf?idNorma=8732>. Acesso em: 20 jul. 2019.

MINAS GERAIS. Secretaria de Estado de Meio Ambiente e Desenvolvimento Sustentável. Conselho Estadual de Política Ambiental. Deliberação Normativa (DN) COPAM n. 220, de 21 de março de 2018. Estabelece diretrizes e procedimentos para a paralisação temporária da atividade minerária e o fechamento de mina, estabelece critérios para laboração e apresentação do relatório de Paralisação da Atividade Minerária, do Plano de Recuperação de Áreas Degradadas - PRAD e do Plano Ambiental de Fechamento de Mina - PAFEM e dá outras providências. Belo Horizonte: COPAM, 2018. Disponível em: $<\mathrm{http}: / /$ www.siam.mg.gov.br/sla/download.pdf?idNorma=45938>. Acesso em: 20 jul. 2019.

MORAIS, J. L. B.; SARAIVA, B. C. O estado de Direito socio-ambiental como condição de possibilidade destinada à tutela do futuro. Veredas do Direito, Belo Horizonte, v. 15, n. 32, p. 11-37, maio/ago. 2018. Disponível em: <http://www.domhelder.edu.br/revista/index.php/veredas/article/ view/1159>. Acesso em: 22 maio 2019. 
NEURAY, G. Des paysages: pour qui? Pourquoi? Comment? Gembloux: Les Presse Agronomique de Gembloux, 1982.

PADUA, S. Afinal, qual a diferença entre conservação e preservação? $O E c o, 2$ fev. 2006. Disponível em: <https://www.oeco.org.br/colunas/ suzana-padua/18246-oeco-15564/>. Acesso em: 10 fev. 2019.

PORTUGAL. Convenção Europeia de Paisagem. Diário da República n. 31.14, de fevereiro de 2005 - I SÉRIE-A. p. 1017-1028. Disponível em: $<$ www.utl.pt/docs/delib4-2005.pdf>. Acesso em 05/09/2006

PRAT, S. Visions picturales et paysages urbains au XIXème siècle: quelques exemples méditerranéens et plus particulièrement celui de Marseille. Cahiers de la Mediterranee, n. 59, p. 197-208, 1999.

PRIEUR, M. M.; LUGINBÜHL, M. Y. Contribution du paysage et de la Convention européenne du paysage à la démocratie, aux droits humains et au développement durable. In: 9e CONFERENCE DU CONSEIL DE L'EUROPE SUR LA CONVENTION EUROPEENNE DU PAYSAGE, 9., 2017, Strasbourg. Strasbourg: Conseil de l'Europe, 2017. p. 1-60. Disponível em: <https://rm.coe.int/conseil-de-1-europe-conventioneuropeenne-du-paysage-10e-conference-du/16809405a4>. Acesso em: 20 jul. 2019.

REZENDE, V. L. A mineração em Minas Gerais: uma análise de sua expansão e os impactos ambientais e sociais causados por décadas de exploração. Sociedade \& Natureza, Uberlândia, v. 28, n. 3, p. 375-384, set./dez. 2016. Disponível em: <http://www.scielo.br/pdf/sn/v28n3/19824513-sn-28-03-0375.pdf>. Acesso em: 20 jul. 2019.

RIBEIRO, J. C. J. et al. Acidentes com barragens de rejeitos da mineração e o princípio da prevenção: de Trento (Itália) a Mariana (Brasil). Rio de Janeiro: Lumen Juris, 2017.

RIBEIRO, J. C. J. A mineração e os ODS. In: $4^{\circ}$ SIMPÓSIO MINERAÇÃO E COMUNIDADES, 4., 2019, Belo Horizonte. São Paulo: Signus, 2019.

RODRÍGUEZ, C. F. La protección del paisaje: un estudio de Derecho español y comparado, Madrid; Barcelona: Marcial Pons, 2007. 
STEWART, P. J.; STRATHERN, A. Landscape, memory and history: anthropological perspectives. London: Pluto Press, 2003.

VYGOTSKY, L. S. Pensamento e linguagem. [s.l.]: Ridendo Castigat Mores, 2009. E-book. Disponível em: <http://www.ebooksbrasil.org/ eLibris/vigo.html>. Acesso em: 15 mar. 2019.

WIRTH, P.; ČERNIČ, B. M.; FISCHER, W. (Eds.). Post-mining regions in Central Europe: problems, potentials, possibilities. München: oekom. 2012. Disponível em: <https://www.ioer.de/fileadmin/internet/IOER_Projekte/ PDF/FB_L/Book_Publication_Post-Mining_Regions_in_Central_Europe. pdf $>$. Acesso em: 20 jul. 2019.

Artigo recebido em: 10/08/2019. Artigo aceito em: 24/09/2019.

\section{Como citar este artigo (ABNT):}

CUSTÓDIO, M. M.; RIBEIRO, J. C. J. Paisagem minerária como elemento de construção do sentimento de pertencimento ao estado de Minas Gerais. Veredas do Direito, Belo Horizonte, v. 16, n. 35, p. 87-121, maio/ago. 2019. Disponível em: <http://www.domhelder.edu.br/revista/index.php/ veredas/article/view/1613>. Acesso em: dia mês. ano. 